\title{
CAVE SETTLEMENT POTENTIAL OF CAVES AND ROCK SHELTERS IN ACEH BESAR REGENCY
}

\section{POTENSI HUNIAN GUA DAN CERUK DI KABUPATEN ACEH BESAR}

\author{
Taufiqurrahman Setiawan \\ Archaeology Research Office of North Sumatera \\ taufiqurrahman.setiawan@kemdikbud.go.id
}

\begin{abstract}
ABSTRAK
Bukti adanya kehidupan masa prasejarah di Aceh telah dibuktikan dengan hasil penelitian arkeologi yang dilakukan oleh Balai Arkeologi Sumatera Utara. Sampai saat ini penelitian masih terfokus di pesisir timur dan pegunungan tengah Aceh, Pesisir barat Aceh belum pernah diteliti. Pesisir barat Aceh merupakan wilayah yang memiliki bentangalam kars cukup luas, dan memiliki potensi gua yang mungkin digunakan sebagai lokasi hunian pada masa lalu. Salah satu metode yang digunakan adalah memprediksi keberadaan gua dengan peta topografi, peta geologi, serta digital elevation model (DEM). Selain itu, hasil inventarisasi gua yang pernah dilakukan di wilayah pesisir barat Aceh juga digunakan sebagai data awal untuk memperoleh sebaran gua dan ceruk. Pada penelitian ini lingkup wilayah yang disurvei adalah Kabupaten Aceh Besar. Tiga parameter gua hunian, yaitu morfologi dan genesa, lingkungan, serta kandungan arkeologis, digunakan untuk memperoleh gambaran potensi masing-masing gua. Sebelas gua dan ceruk yang telah ditemukan menunjukkan adanya tiga buah gua berpotensi sebagai lokasi hunian dan diteliti lebih lanjut, empat gua berpotensi sebagai lokasi hunian tetapi tidak berpotensi untuk diteliti, dan empat gua berkategori tidak potensial sebagai lokasi hunian.
\end{abstract}

Kata Kunci: Gua; Ceruk; Karst; Pesisir Barat Aceh; Prasejarah

\section{ABSTRACT}

The evidence of prehistoric life in Aceh has been proven by the results of archeological research conducted by the Archaeology Research Office of North Sumatera. Until now, the research only focuses on the eastern coast and the central mountains of Aceh. The western coast of Aceh, which also has the potential to provide information, has never been studied. The western coast of Aceh is an area that has a wide karst landscape with many caves that might be used as a settlement in the past. One method used to predict such caves included a topographic map, a geological map, and a digital elevation model (DEM). The inventory results of caves on the western coast of Aceh were also used as preliminary data to obtain the distribution of caves and rock shelters. In this study, the area surveyed was Aceh Besar Regency. Three parameters of inhabited caves, i.e. morphology and genesis, environment, and archaeological content, were used to describe the potential of each cave. Of eleven caves and rock shelters, three caves are qualified as the past settlement and potential for further research, four caves are qualified as the past settlement but not potential for further research, and four caves are neither qualified as a settlement.

Keywords: Caves; Rock Shelters; Karst; Western Coast of Aceh; Prehistory

Article Submitted $\quad: 11-12-2019$

Article Accepted : : :01-04-2020 


\section{INTRODUCTION}

Archaeological research in prehistoric times in Aceh Province by the Archaeology Research Office of North Sumatera has been performed at several sites. The research results indicate evidence for the existence of prehistoric habitations with Hoabinh cultural characteristics, e.g. those at Bukit Kerang Pangkalan site in Aceh Tamiang Regency. This open site is believed to be habitation during 12,000-3,000 BP (before present) with archaeological findings such as sumatralith stone tools, grinding stones, and folded burials (Wiradnyana, 2011). Other research conducted in Loyang Mendale Cave, Loyang Ujung Karang Cave, and Putri Pukes Cave located on the edge of Lake Lut Tawar in the central mountains of Aceh give evidence of settlements since 9,000 BP. In these three sites, the data on artifacts, ecofacts, features, and the inhabitants are found. The habitation at the cave sites suggests the influence of Hoabinh and Austronesian culture as indicated by the archaeological findings such as sumatralith stone tools and stone adzes (Wiradnyana \& Setiawan, 2011).

The conducted research still focuses on sites on the eastern coast and central mountains of Aceh, then what about prehistoric life on the western coast of Aceh? Does it also have cultural similarities with the central region and eastern coast of Aceh? The lack of archeological information on Aceh's western coast has left these questions unanswered. Therefore, an archeological study needs to be performed in the regions so that it can provide an overview of life in Aceh's western coast.

The western coast of Aceh is the area with the largest karst landscape in Sumatra Island that has the potential for the existence of caves or rock shelters. The use of caves and rock shelters as a settlement in the past has also been proven in archeological studies. The karst region in Aceh is divided into two big groups, i.e. the western part and the middle part. The west karst spreads along the Western coast of Aceh and intermittently consists of Lam Badeuk Karst, Mata Ie Karst, Lampuuk Karst, Lhok Nga Karst, Leupung Karst, Lamno Karst, Teunom Karst, Labuhan Haji Karst, and Tapak Tuan Karst. Meanwhile, the central karst landscape stretches from Laweung, Mount Peut Sagoe, Lake Laut Tawar, Isaq, Pining, Serbajadi, and Tamiang Hulu. In the two karst landscapes, information about caves is already obtained, including Lhok Mata Ie Cave, Apamani Cave, Mon Cave, Kameng Cave, Landak Cave, Celah Cave, Lima Cave, Lontie Cave (small bat), Lubang Jarum Cave, Hijau Cave, Babah Ie Cave, Pari Cave, Sagop Cave, Gle Glungku Cave, Tanoh Anoe Cave, Teumbiga Cave, Pinto Tujoh Cave, Harimau Cave, Loyang Koro Cave, Loyang Putri Pukes Cave, Loyang Datu Cave, Loyang Kameng Cave, Weih Lop Cave, Demer Gantung Cave, Umah Atu Cave, Batu Kapur Cave, Kemenyan Cave, and Atu Janggut Cave (UKM PA Leuser, 2004).

Data on the distribution of caves on the western coast of Aceh is also obtained from the results of the Sumatra Speleolog Expedition conducted by DR. Louis Deharveng (MNHN, France) and DR. Francois Brouquisse (Wanadoo, France) in the 1990s. This expedition was continued in February 2000 by Dr. G. M. Drawhorn with the title Indonesian-International Sumatran Cave Research and Exploration Expedition, so this expedition can be used as preliminary data as well. During the expedition, 31 caves were inventoried. The expedition was intended to explore the tourism potential of the cave and conducted on all types of caves or 
rock shelters, namely active caves, underground river networks, ponor (vertical caves), and fossil caves (Drawhorn, 2000); see Table 1 no. 1-31. The caves with archeological contents have not been inventoried in these projects. The distribution of caves in this region is also obtained from the Indonesian Speleological Society website (Masyarakat Speleologi Indonesia, 2013); Table 1 no. 32-46. The web page shows the distribution of 15 caves with no information about the archaeological potential in them.

Table 1. List of inventoried caves as preliminary data

\begin{tabular}{|c|c|c|c|}
\hline NO & $\begin{array}{c}\text { CAVE/ ROCK } \\
\text { SHELTERS/ PONOR }\end{array}$ & LOCATION & NOTES \\
\hline 1. & Halu Hijau Cave & Lhok Nga, Aceh Besar & $\begin{array}{l}\text { Whitten, 1987; } \\
\text { Deharveng, } 2000\end{array}$ \\
\hline 2. & Maniang Cave & Lhok Nga, Aceh Besar & Deharveng, 2000 \\
\hline 3. & Mangsa Cave & Lhok Nga, Aceh Besar & Whitten, 1987 \\
\hline 4. & Hilup Cave & Lhok Nga, Aceh Besar & Deharveng, 2000 \\
\hline 5. & Sementua Cave & Lhok Nga, Aceh Besar & Deharveng, 2000 \\
\hline 6. & Kreung Rang Cave & Lhok Nga, Aceh Besar & Deharveng, 2000 \\
\hline 7. & Kelelawar Cave & Lam Peuek, Aceh Besar & Deharveng, 2000 \\
\hline 8. & Sarang Cave & Lam Peuek, Aceh Besar & Deharveng, 2000 \\
\hline 9. & Alu Groh Cave & Leupung, Aceh Besar & Deharveng, 2000 \\
\hline 10. & Kreung Riting Cave & Leupung, Aceh Besar & Deharveng, 2000 \\
\hline 11. & Lhok Ek Cave & Lhok Nga, Aceh Besar & Deharveng, 2000 \\
\hline 12. & Jantang Cave & Loong, Aceh Besar & \\
\hline 13. & Raya Cave & Desa Paroy Indah & \\
\hline 14. & Puyu Kreueng Cave & Lhok Nga, Aceh Besar & Deharveng, 2000 \\
\hline 15. & Raba Hung Cave & Kreueng Hung & Deharveng, 2000 \\
\hline 16. & Ulee Cave & Dekat Pantai Cemara & Deharveng, 2000 \\
\hline 17. & Tujuh Cave & $\begin{array}{l}\text { Minasah dan Desa Kayee Kuniet, } \\
\text { Pidie }\end{array}$ & \\
\hline 18. & Lobang Meunasah & Desa Meunasah, Pidie & Deharveng, 2000 \\
\hline 19. & An anonymous cave & Desa Meunasah, Pidie & Deharveng, 2000 \\
\hline 20. & Krueng Cave & Desa Meunasah Lhok, Pidie & Deharveng, 2000 \\
\hline 21. & Pari Cave & Desa Tchot, Pidie & Deharveng, 2000 \\
\hline 22. & Manjang Cave & Desa Keutapang, Pidie & Deharveng, 2000 \\
\hline 23. & Teumiga Cave & $\begin{array}{l}\text { Desa Ujung Suden, Lamno, Aceh } \\
\text { Jaya }\end{array}$ & \\
\hline 24. & $\begin{array}{l}\text { A cave near Lhok } \\
\text { Geulumpang }\end{array}$ & Lhok Geulumpang, Aceh Jaya & \\
\hline 25. & Muslimin Cave & Sawang, Tapak Tuan, Aceh Selatan & Deharveng, 2000 \\
\hline 26. & Kiciran Cave & $\begin{array}{l}\text { Darur Makmur, Tapak Tuan, Aceh } \\
\text { Selatan }\end{array}$ & Deharveng, 2000 \\
\hline 27. & Air Pinang Cave & Air Pinang, Sungai Alur Kering & Deharveng, 2000 \\
\hline 28. & Kalam Cave & Jampu Apha & Deharveng, 2000 \\
\hline 29. & Panjupian Cave & $\begin{array}{l}\text { Panjupian, Tapak Tuan, Aceh } \\
\text { Selatan }\end{array}$ & Deharveng, 2000 \\
\hline 30. & Sawastingkeum Cave & Bakongan, Sawastingkeum, & Deharveng, 2000 \\
\hline 31. & Ujung Batu Cave & & Deharveng, 2000 \\
\hline 32. & Pulau Ujung Batu Cave & $\begin{array}{l}\text { Teluk Nibung, Pulau Banyak, Aceh } \\
\text { Singkil }\end{array}$ & www.peta.caves.or.id \\
\hline 33. & Pasir Panjang Cave & $\begin{array}{l}\text { Pulau Tuangku, Pulau Banyak, Aceh } \\
\text { Singkil }\end{array}$ & www.peta.caves.or.id \\
\hline 34. & Tambegu Cave & $\begin{array}{l}\text { Pulau Tuangku, Pulau Banyak, Aceh } \\
\text { Singkil }\end{array}$ & www.peta.caves.or.id \\
\hline 35. & Pucung Krueng Cave & Raba, Lhok Nga, Aceh Besar & www.peta.caves.or.id \\
\hline 36. & Maniang Cave & Baro, Lhok Nga, Aceh Besar & www.peta.caves.or.id \\
\hline 37. & Ulee Cave & Baro, Lhok Nga, Aceh Besar & www.peta.caves.or.id \\
\hline 38. & Krueng Rang Cave & Baro, Lhok Nga, Aceh Besar & www.peta.caves.or.id \\
\hline 39. & Ritieng Cave & Leupung, Lhok Nga, Aceh Besar & www.peta.caves.or.id \\
\hline
\end{tabular}




\begin{tabular}{|c|c|c|c|}
\hline NO & $\begin{array}{c}\text { CAVE/ ROCK } \\
\text { SHELTERS/ PONOR }\end{array}$ & LOCATION & NOTES \\
\hline 40. & Hilup Cave & Baro, Lhok Nga, Aceh Besar & www.peta.caves.or.id \\
\hline 41. & Meunasah I \& II Caves & Meunasah, Lhoong, Aceh Besar & www.peta.caves.or.id \\
\hline 42. & Muslimin Cave & $\begin{array}{l}\text { Simpang Tiga, Sawang, Aceh } \\
\text { Selatan }\end{array}$ & www.peta.caves.or.id \\
\hline 43. & Kiciarean Cave & $\begin{array}{l}\text { Tring Menduro Tunong, Sawang, } \\
\text { Aceh Selatan }\end{array}$ & www.peta.caves.or.id \\
\hline 44. & Kalem Cave & $\begin{array}{l}\text { Tapaktuan, Tapaktuan, Aceh } \\
\text { Selatan }\end{array}$ & www.peta.caves.or.id \\
\hline 45. & Pinang Cave & $\begin{array}{l}\text { Air Pinang, Tapaktuan, Aceh } \\
\text { Selatan }\end{array}$ & www.peta.caves.or.id \\
\hline 46. & Ujung Batu Cave & $\begin{array}{l}\text { Ujung Batu, Tapaktuan, Aceh } \\
\text { Selatan }\end{array}$ & www.peta.caves.or.id \\
\hline
\end{tabular}

Aceh's Western coast currently belongs to nine administrative regions, i.e. Aceh Besar Regency; Aceh Jaya Regency; West Aceh Regency; Nagan Raya Regency; Southwest Aceh Regency; City of Subussalam; Southeast Aceh Regency; South Aceh Regency; Aceh Singkil Regency (Figure 1). Aceh Besar Regency is the first area successfully surveyed in a 2018 study by the Archaeology Research Office of North Sumatera. Eight other areas have not been surveyed. Therefore, the scope of this current study includes caves and rock shelters which are located in Aceh Besar Regency only.

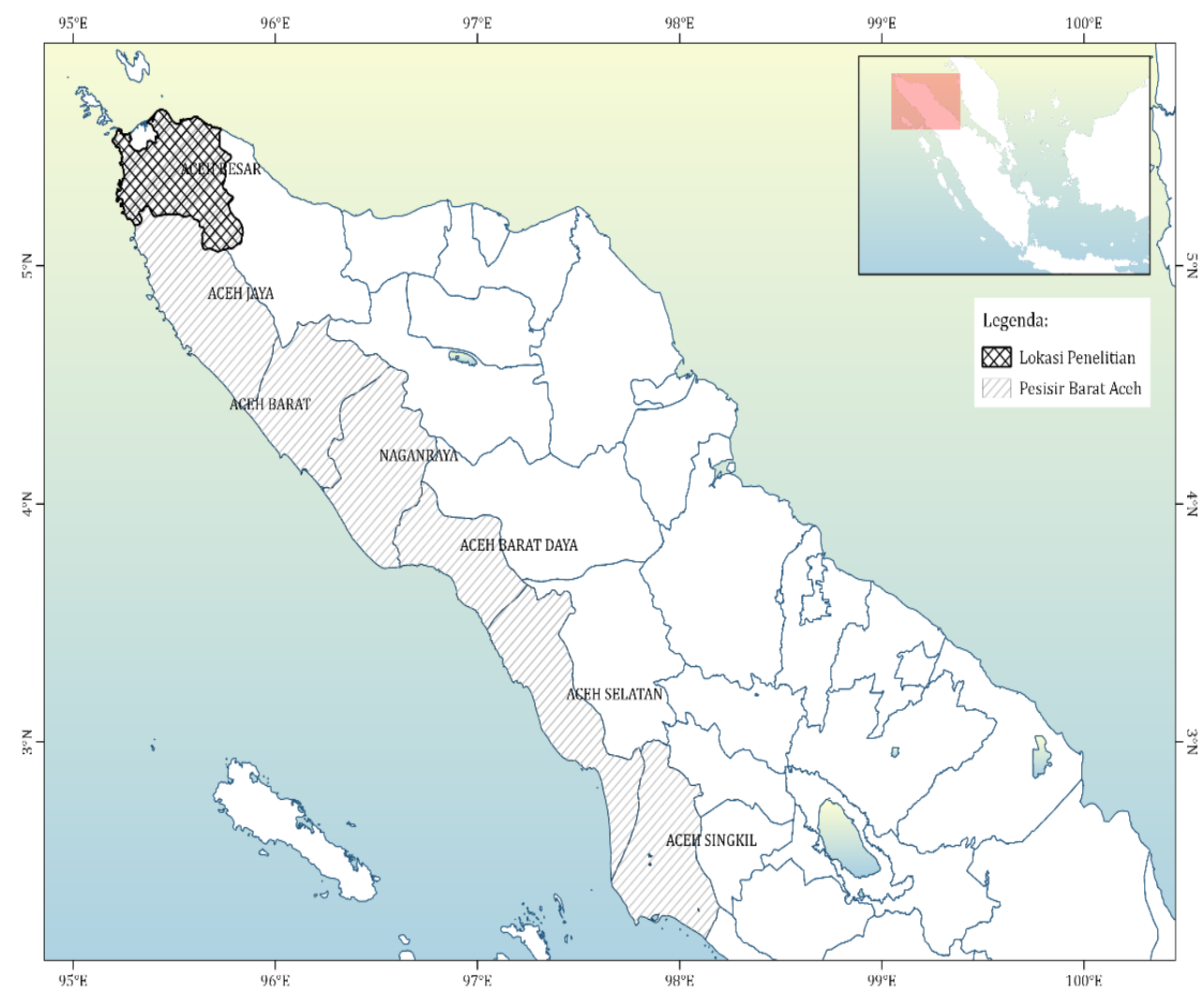

Figure 1. Research Location and Western coastal region of Aceh (Source: Archaeology Research Office of North Suumatera, 2018) 


\section{METHODS}

This study was conducted in three stages, namely 1) pre-fieldwork, 2) fieldwork, and 3) post-fieldwork. The pre-fieldwork stage was a literature review to find out initial information about the caves, the environment, geology, and geomorphology in the research location. The materials for predicting the existence of caves were collected at this stage, including a 1: 50,000 scale topographic map; Geological Map scale 1: 250,000; Satellite Imagery; and Digital Elevation Model (DEM). The information about the existence of caves and rock shelters from library sources was also collected. Next, the data collection in the field was performed by observing the prediction results of the existence of the caves in the pre-fieldwork stage. The data on caves was collected based on three parameters, i.e. morphology and morphogenesis; environment; and archaeological content (Yuwono, 2005). The results of data collection in the field were then classified and analyzed. The outputs from the field data collection included a map of the cave distribution and the cave potential as a settlement as well as the potential for further research.

The morphological parameters (morphography and morphometry) include the shape, size, and aspects of the micro-space of the observed caves. In general, caves containing settlement potential are the umbrella cave (rock shelter) and other horizontal caves in the form of dry caves. An inhabited cave has a space that can protect from the weather and climate as well as can enable daily activities. A dry floor with good lighting and air circulation is one of the determining factors in choosing a cave to be inhabited. The thickness of the floor sediments is also an important factor, considering the thicker the cave sediments, the higher the possibility of deposited elements.

Environmental parameters concern the condition of the physical environment and the location of the cave in the context of the surrounding landscape. Observations were made by taking into account aspects of the position and differences in the height of the cave and the valley floor, the slope, the shape of the valley, and the factors of distance and availability of water sources. The closer the distance and the ease of obtaining food resources, water, and other daily activities, the greater the cave is chosen as a settlement location (Legge, 1972; Yuwono, 2005).

The environment is one of the determinants of humans choosing a settlement location. Therefore, humans pay attention to environmental conditions and technological mastery. Several variables related to environmental conditions include the availability of water sources, the presence of shelter, the condition of the soil that is not too humid, the ease of obtaining food resources and the factors that provide additional elements of marine animals or aquatic animals (near shore, lakes, rivers, springs) (Butzer, 2006; Subroto, 1995, pp. 133-138).

The archaeological content includes indications of archaeological evidence found on the surface and under the surface of the cave floor and paintings or scratches on the walls and ceiling of the cave. This parameter illustrates the existence of evidence of the use of a cave as a settlement and has the potential to be investigated or not (Yuwono, 2005).

The results of the identification of caves were then analyzed further to get the potential category of the cave. In this study, the potential of the cave is divided into three categories, i.e. (Setiawan, 2012): 
1. Qualified as a settlement and potential for further research (potential I) given when three parameters are met,

2. Qualified as a settlement but not potential for further research (potential II) given when the morphological parameter is met or added with one qualified parameter: environment or archeological content,

3. Not potential given when all three parameters are not met.

\section{RESEARCH RESULTS}

The results of field data collection conducted in Aceh Besar Regency found data on 19 (nineteen) caves and rock shelters. In this study, only 11 caves are surveyed (see Table 2; see Figure 14). The other eight caves are not surveyed due to limited supporting equipment to reach the caves, no permit obtained because the cave is used as a swallow's nest, and no guides/informants know the caves' locations.

Table 2. Data on the Caves and Rock shelters in Aceh Besar Regency in 2018

\begin{tabular}{|c|c|c|c|c|}
\hline NO & SITE NAME & VILLAGE & SUBDISTRICT & NOTE \\
\hline 1 & Ek Leuntie Cave & Menasah Lhok & Lhoong & Surveyed \\
\hline 2 & Pari Cave & Menasah Cot & Lhoong & Surveyed \\
\hline 3 & Tuandigedong Cave & Keutapang & Lhoong & Surveyed \\
\hline 4 & Udang Cave & Keutapang & Lhoong & Surveyed \\
\hline 5 & Pucuk Krueng Cave & Raba & Lhoknga & Surveyed \\
\hline 6 & Menasah Krueng I Cave & Menasah Krueng & Lhoong & Surveyed \\
\hline 7 & Mabitce Cave & Deah Mamplam & Leupung & Surveyed \\
\hline 8 & Lhoong Pigip Cave & Menasah Krueng & Lhoong & Surveyed \\
\hline 9 & Lhoknga 1 Rock Shelter & Mon Ikheun & Lhoknga & Surveyed \\
\hline 10 & Tebing Lampuuk Cave & Lampuuk & Lhoknga & Surveyed \\
\hline 11 & Ek Manuk Cave & Lampuuk & Lhoknga & Surveyed \\
\hline 12 & Sarang Cave & Lampuuk & Lhoknga & Surveyed \\
\hline 13 & Lam Kenurung Cave & Lampuuk & Lhoknga & Not surveyed \\
\hline 14 & Kameng Cave & Nagaombang & Lhoknga & Not surveyed \\
\hline 15 & Semantung Cave & Deah Mamplam & Leupung & Not surveyed \\
\hline 16 & Abah Luh Cave & Deah Mamplam & Leupung & Not surveyed \\
\hline 17 & Papan Cave & Deah Mamplam & Leupung & Not surveyed \\
\hline 18 & Sampan Cave & - & Lhoong & Not surveyed \\
\hline 19 & Semantung Cave & Meunasah Krueng & Lhoong & Not surveyed \\
\hline
\end{tabular}

\section{Ek Leuntie Cave}

This cave has a direction facing south with an L-shaped interior with the front interior facing north-south and located on the lower slope of a hill that is right on the edge of the coastline. The morphology of the cave space is very wide and 
has good air circulation and good light intensity. The cave floor is relatively flat with sediment conditions that have now been lost due to guano mining activities. On the surface, the cave floor, pottery fragments, fragments of clamshells, fireplace features, andesite stone manuport, and lithics (?) are found (Figure 2).

In 2012, this cave was studied by Charles M. Rubin et al. The results of radiocarbon dating and stratigraphic analysis of the six excavation boxes on the inside of this cave indicate that 11 ancient tsunamis have occurred since 7,400-2,900 $\mathrm{BP}$ with intervals of an average of 450 years. For a period after 2,000 BP, a number of tsunamis also occurred, but cannot be identified because the layers are severely damaged (unconformity) (Rubin, et al., 2012, pp. 2-4).

The excavation process done in 2012 was a geological excavation, so that the possibility of the existence of cultural findings in the stratigraphic layers is not one of the focuses of this research. Therefore, it is also necessary to trace archeological contents that might be found in this cave. Considering that the sediment in the front of the cave is damaged a lot, excavation can be focused on the part of the cave that has floor sediments and is likely to be used as a location for human activities.

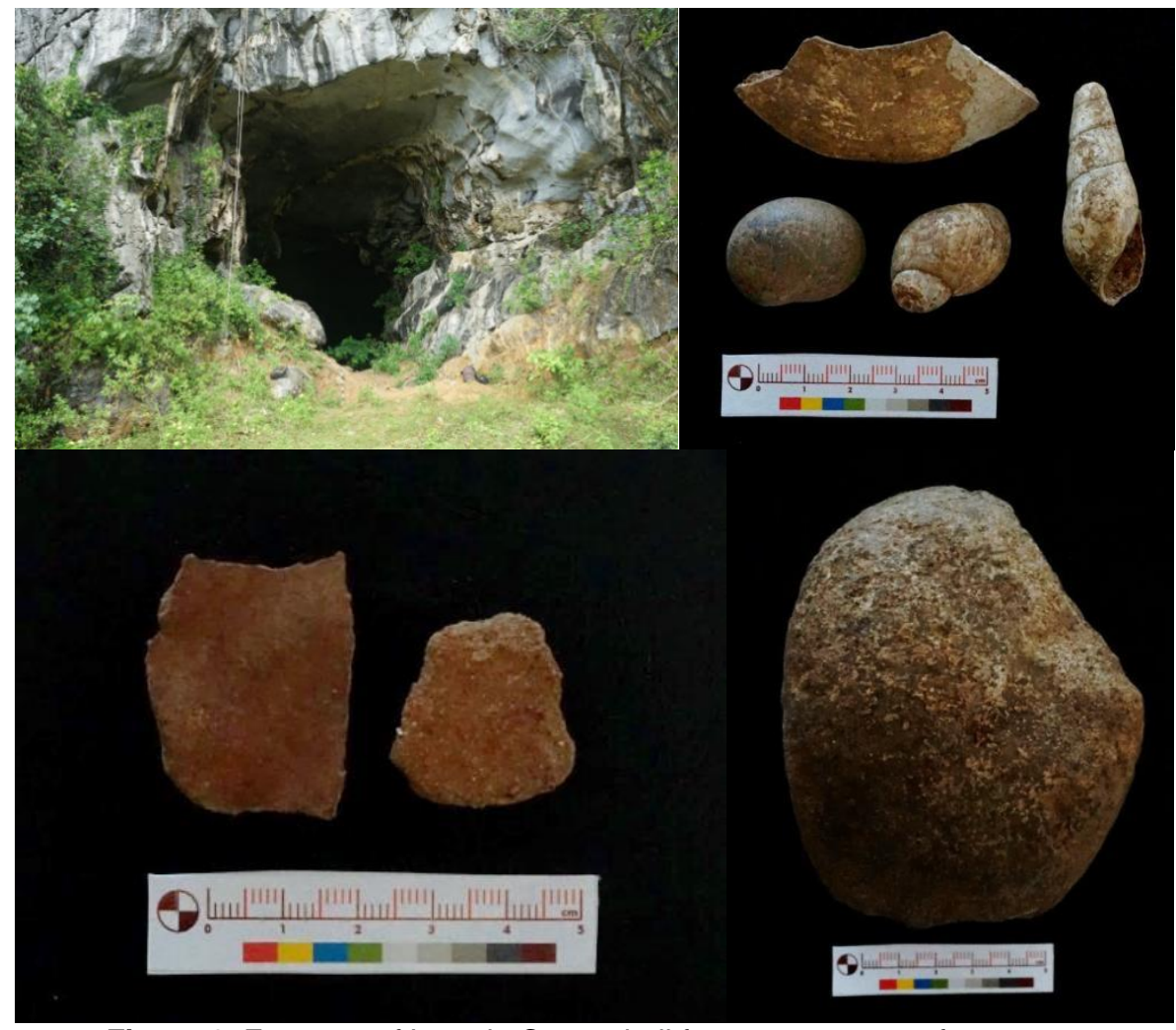

Figure 2. Entrance of Leuntie Cave, shell fragments, pottery fragments, and andesite stone manuport

(Source: Archaeology Research Office of North Suumatera, 2018)

\section{Pari Cave}

Pari Cave is located in Gampong Meunasah Cot, Lhoong Sub-district. This cave faces to the southwest at the coordinate $5.216581^{\circ}$ North Latitude and 95.2840750 East Longitude (UTM 46N 753181.07 Mt 753181.07 Mu). The cave mouth is on the lower slope of a hill that is right on the side of the Banda Aceh - 
Meulaboh Highway. The morphology of the space is very broad and has good air circulation but the light intensity is not good. The entrance of this cave is quite low and narrow. At the back of the cave space, underground channels are still found. At the front, i.e. the left side of the entrance, a retaining wall made from cement is found. At this location, two tombs facing the north-south are also found (Figure 3). In the two tombs, there is no writing on the tombstone. The tomb and the tombstone are made of river stone and one of the tombs uses cement.

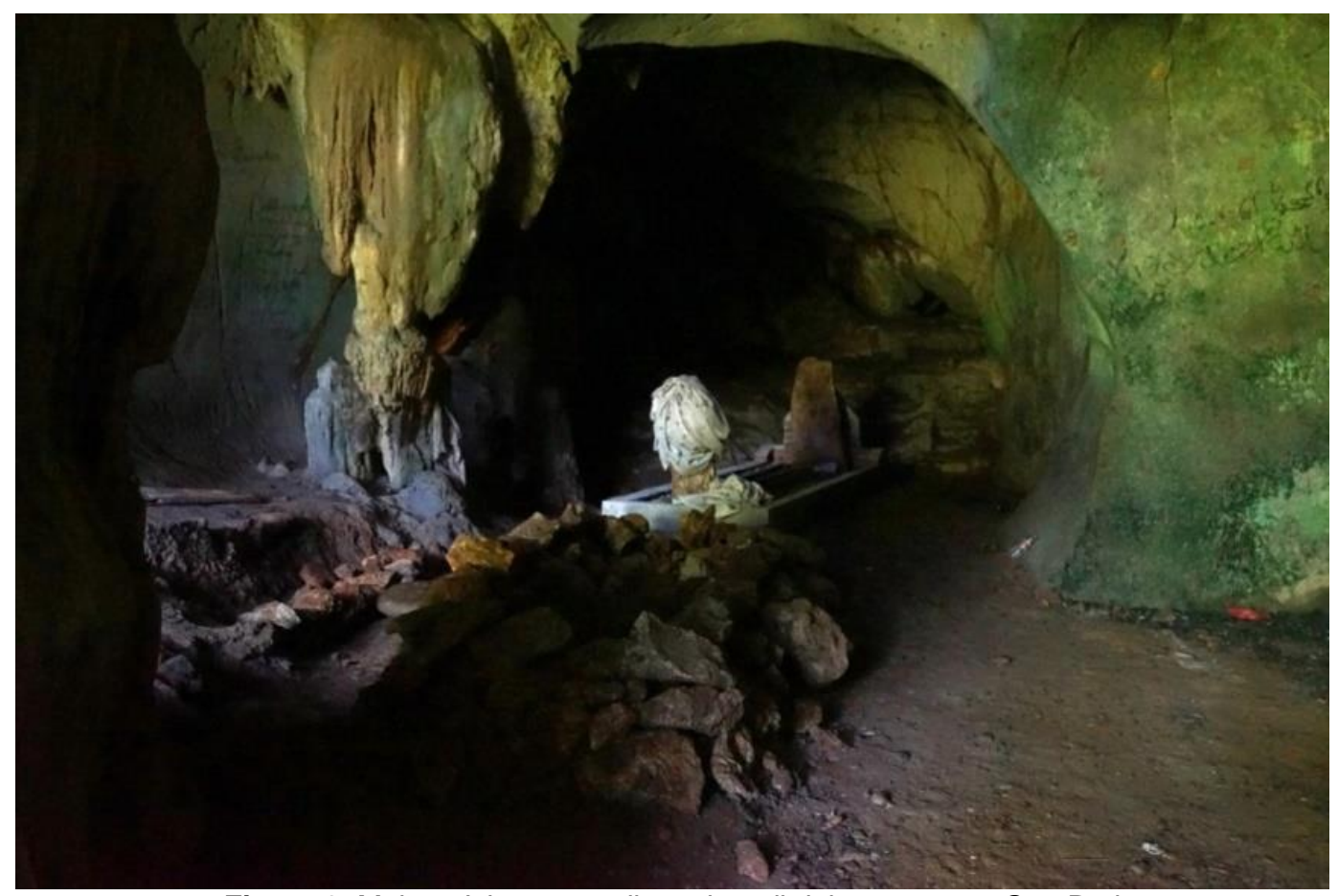

Figure 3. Makam Islam yang ditemukan di dalam ruangan Gua Pari (Sumber: Dok. Archaeology Research Office of North Suumatera, 2018)

\section{Tuandigedong Cave}

Tuandigedong Cave is located in Keutapang Village, Lhoong Sub-district, Aceh Besar Regency. The cave mouth is right on the side of the Banda AcehMeulaboh Highway and on the lower slope of Lhoong karst hills. The cave which is located at the coordinate $5.222188^{\circ}$ North Latitude and $95.278012^{\circ}$ East Longitude (UTM 46N 752506.41 577681.77) has a very broad spatial morphology with two entrances facing south $\left(180^{\circ}\right)$ with the relatively flat and dry floor surface. The intensity of lighting and air circulation is very good. The location of this cave is in the same hill as Pari Cave which is located in the south. This cave is also about 1 $\mathrm{km}$ from Krueng Lhoong in its north and about $2 \mathrm{~km}$ from the present coastline in the west. Currently, people use this cave for guano mining. Therefore, most of the cave floor in the inner part of the cave space has been dug up to the basic rocks, especially in the back. The part that is still relatively preserved is still found at the entrance of the cave and the southern part of the space. In this location, there is quite a lot of andesite stone manuport which probably came from Krueng Lhoong in the north, but there are no lithic artifacts found at the time of the survey. The surface findings in this cave are animal bone fragments (Figure 4). 


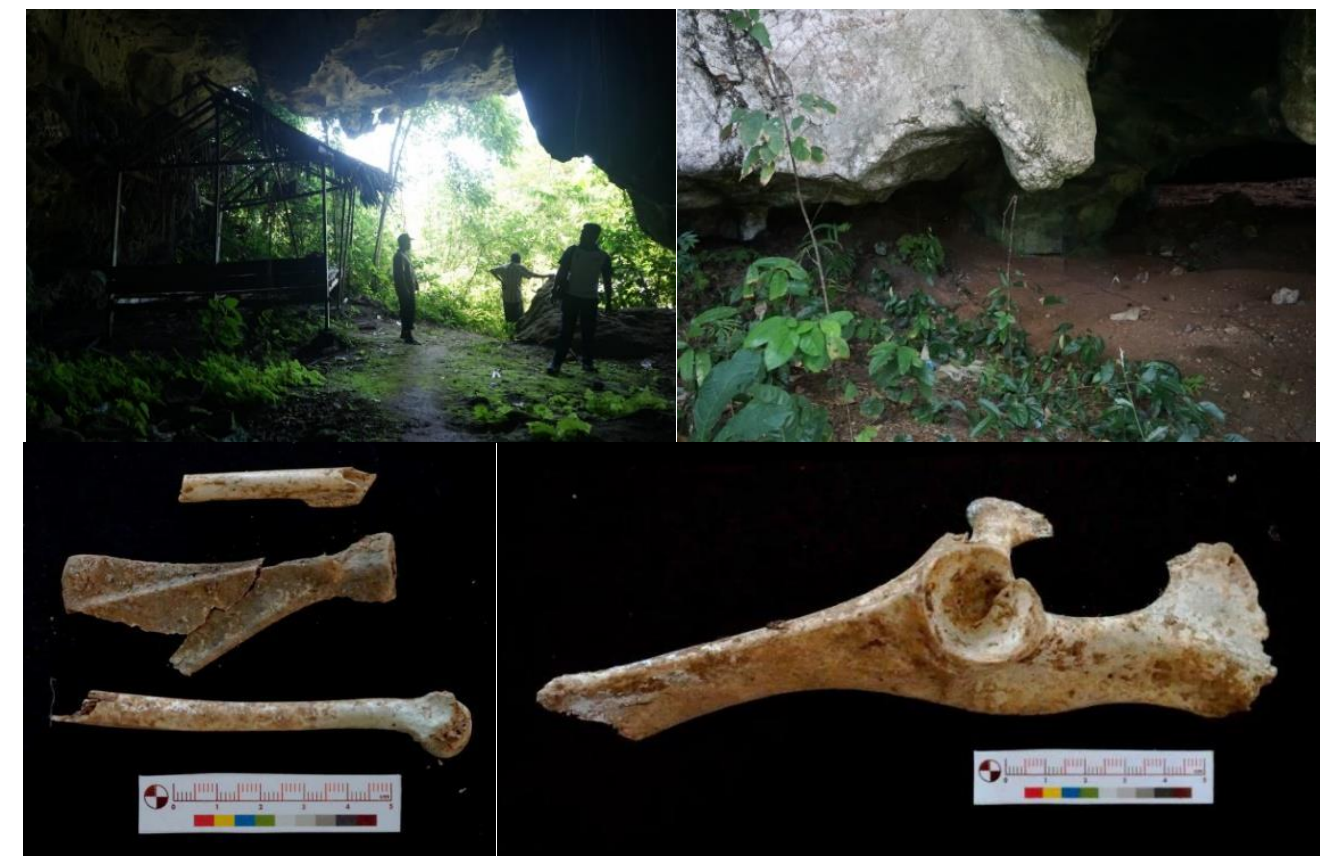

Figure 4. The front space and entrance of Tuandigedong Cave, and bone fragments found on the floor surface

(Source: Archaeology Research Office of North Suumatera, 2018)

\section{Udang Cave}

Udang Cave is located $1.3 \mathrm{~km}$ north of Tuan Cave in Gedong. The location of the cave belongs to the administrative area of Keutapang Village, Lhoong Subdistrict, and is at $5.230500^{\circ}$ North Latitude and $95.272004^{\circ}$ East Longitude (UTM $46 \mathrm{~N} 751836.79 \mathrm{mT} 578598.88 \mathrm{mU}$ ). This cave is located on the lower slope of a hill with flat land in front of it. The distance between the cave and the coastline is about $2 \mathrm{~km}$. The cave has a narrow cave mouth with poor lighting because people can only enter the cave mouth (Figure 5).

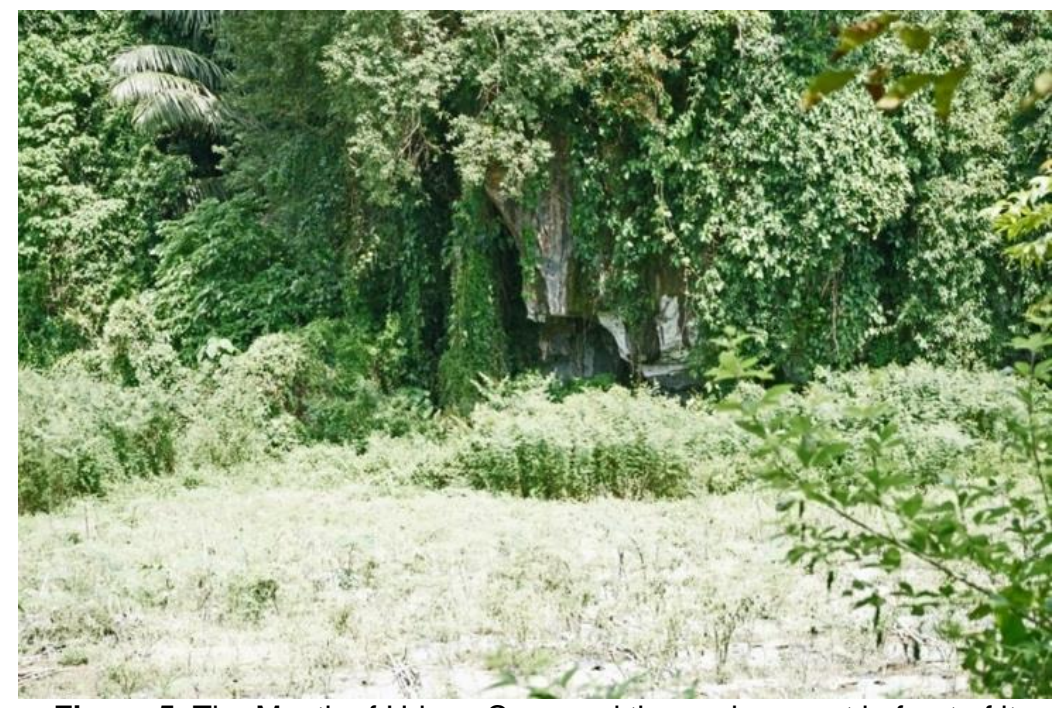

Figure 5. The Mouth of Udang Cave and the environment in front of it (Source: Archaeology Research Office of North Suumatera, 2018) 


\section{Pucuk Krueng Cave}

Pucuk Krueng Cave is a subsurface river outlet which then becomes the upstream of Krueng Raba. This location has now been used as a dam and tourist attraction. This cave is located in Gampong Raba, Lhok Nga Sub-district, and is located at $5.459932^{\circ}$ North Latitude and $95.261623^{\circ}$ East Longitude (UTM 46N $750592.15 \mathrm{Mt} 603975.62 \mathrm{Mu})$. In general, three caves/rock shelters are found at different levels.

The lowest cave still functions as a subsurface river network. At the top of the cave, there are two other rock shelters. In the two caves, their archaeological content cannot be obtained due to their position on an upright slope wall. To reach the location needs certain climbing equipment (Figure 6).

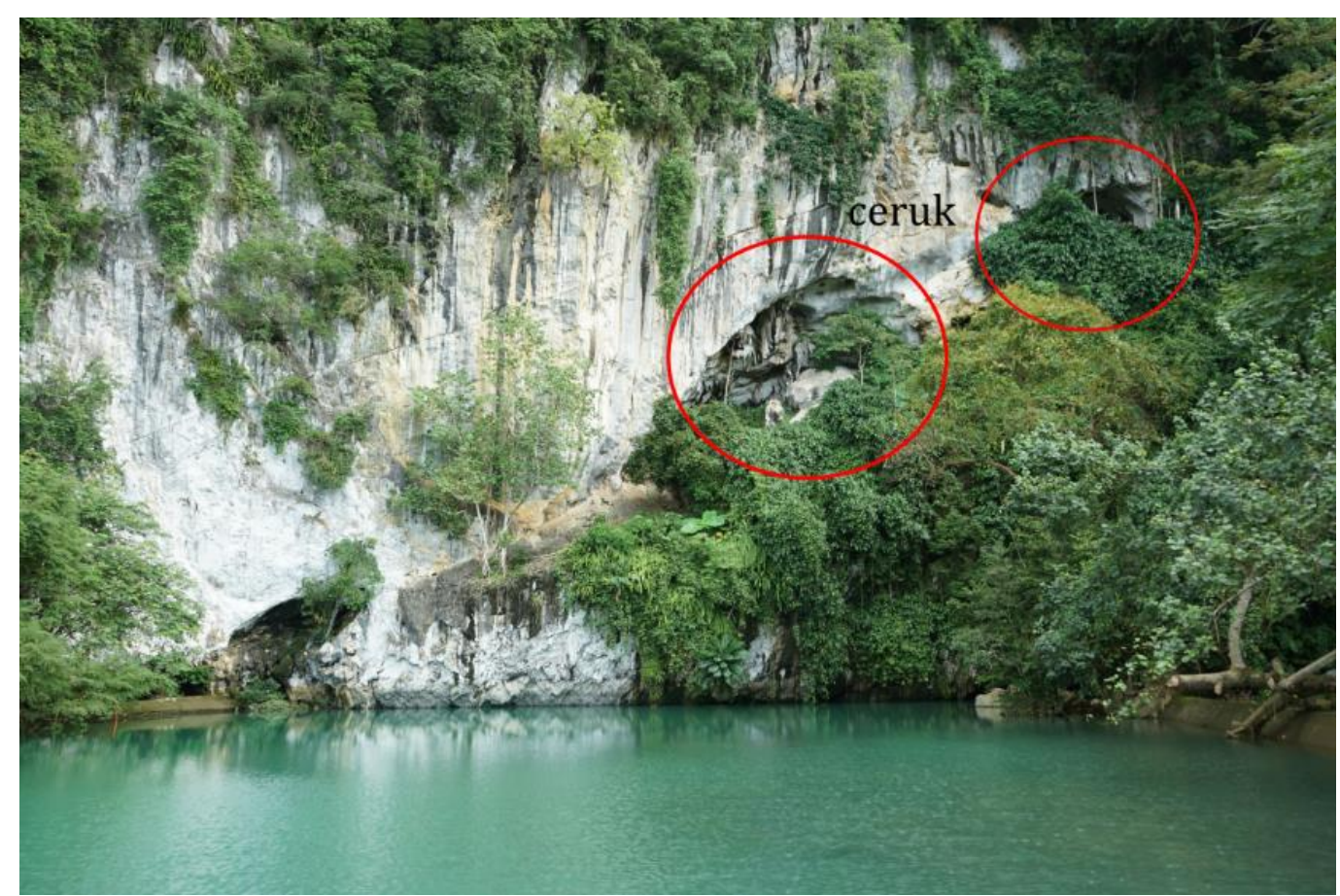

Figure 6. Pucuk Krueng Cave and the surrounding environment (Source: Archaeology Research Office of North Sumatera, 2018)

\section{Meunasah Krueng I Cave}

Meunasah Krueng I Cave is a naming given by the researchers because there is no local name. This cave is on the opposite side of the Lhoong Pigip Cave. The morphology of the cave floor resembles a ponor (vertical cave) whose lower part is slightly flat. This cave is located at $5.282882^{\circ}$ North Latitude and $95.245906^{\circ}$ East Longitude (UTM $46 \mathrm{~N} 748921.7 \mathrm{Mt} 584383.15 \mathrm{Mu}$ ). The mouth of the cave faces $220^{\circ}$ southwest with steep slopes to reach the mouth of the cave. The lighting and air circulation are poor due to its vertical cave shaft. The floor of the cave is dry and has thin sediments. At this location, only one ceramic fragment was found. A ceramic fragment of the body part was found on the surface of the cave floor. The ceramic is made from stoneware with a coiling technique. This ceramic fragment 
is dark brown with a damaged glaze. This ceramic is a Southeast Asian ceramic that developed in the XV-XVI AD century (Figure 7).

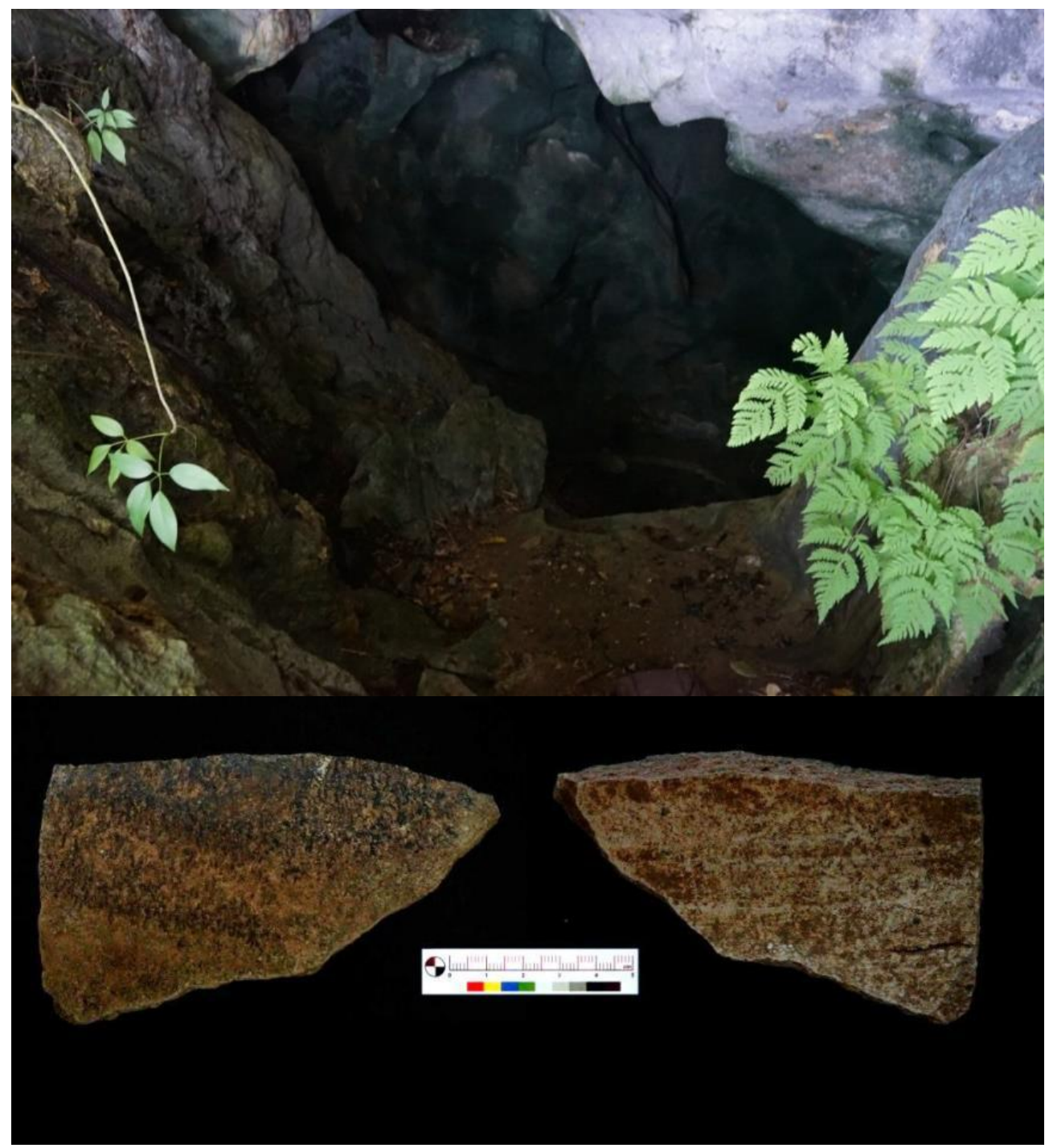

Figure 7. The interior of Meunasah Krueng I Cave and ceramic fragments found on the floor surface (Source: Archaeology Research Office of North Suumatera, 2018)

\section{Mabitce Cave}

Mabitce Cave is located in the karst region of Leupung. Administratively, it belongs to the area of Gampong Deah Mamplam, Leupung Sub-district, Aceh Besar Regency and is located at the coordinate $5.402038^{\circ}$ North Latitude and 95.2579090 East Longitude (UTM 46N 750204.32 597569.56). The mouth of the cave is on the southern central slope of the Leupung karst hill with a height difference with the valley floor of about 10-15 meters. The front of this cave is a plain used as a rice field and is located about $1 \mathrm{~km}$ from the beach. The mouth of the cave faces southwest $\left(260^{\circ}\right)$ with a height of $16.4 \mathrm{~m}$ and a width of $11.5 \mathrm{~m}$. The slope in front of the mouth of the cave is steep with a slope of about $45^{\circ}$. The cave has a deep L- 
shaped interior with a space height of $17.4 \mathrm{~m}$ with a width of the interior between 10-11.5 m. The floor of the cave is dry and flat with excellent air circulation and lighting. On the inside, the cave floor has been disturbed a lot by guano mining activities so that the sediment conditions are disturbed and very thin. At the front close to the mouth of the cave, the condition of the sediment is still relatively undisturbed.

Another finding is the feature of two shell layers that are already fused (compact) like layers found at the sites of Bukit Kerang on the eastern coast of Sumatra. The two layers of the shell are composed of two different types of shells and separated by a different layer of soil. The clamshell layer at the top is dominated by bivalve class which is a shell with a marine or brackish water habitat. The lower shell layer is dominated by gastropods (Telescopium) whose habitat is in freshwater and brackish water (Figure 8).

The existence of two shell layers and two different layers which are separated by one layer of intermediate soil gives an illustration that the two layers were formed not at one time simultaneously. The existence of a compact shell layer that shows conformity illustrates that the layer is a stratigraphic layer composed naturally (natural-transform), not a result of human activities that bring shells into the cave shells (cultural-transform). The genesis of the formation of this layer until it can be deposited in the cave is still a question, given the insufficient data obtained to answer it. Therefore, research is needed to reveal the process and its chronology by conducting a radiocarbon analysis on the two shell layers (Setiawan, 2018).

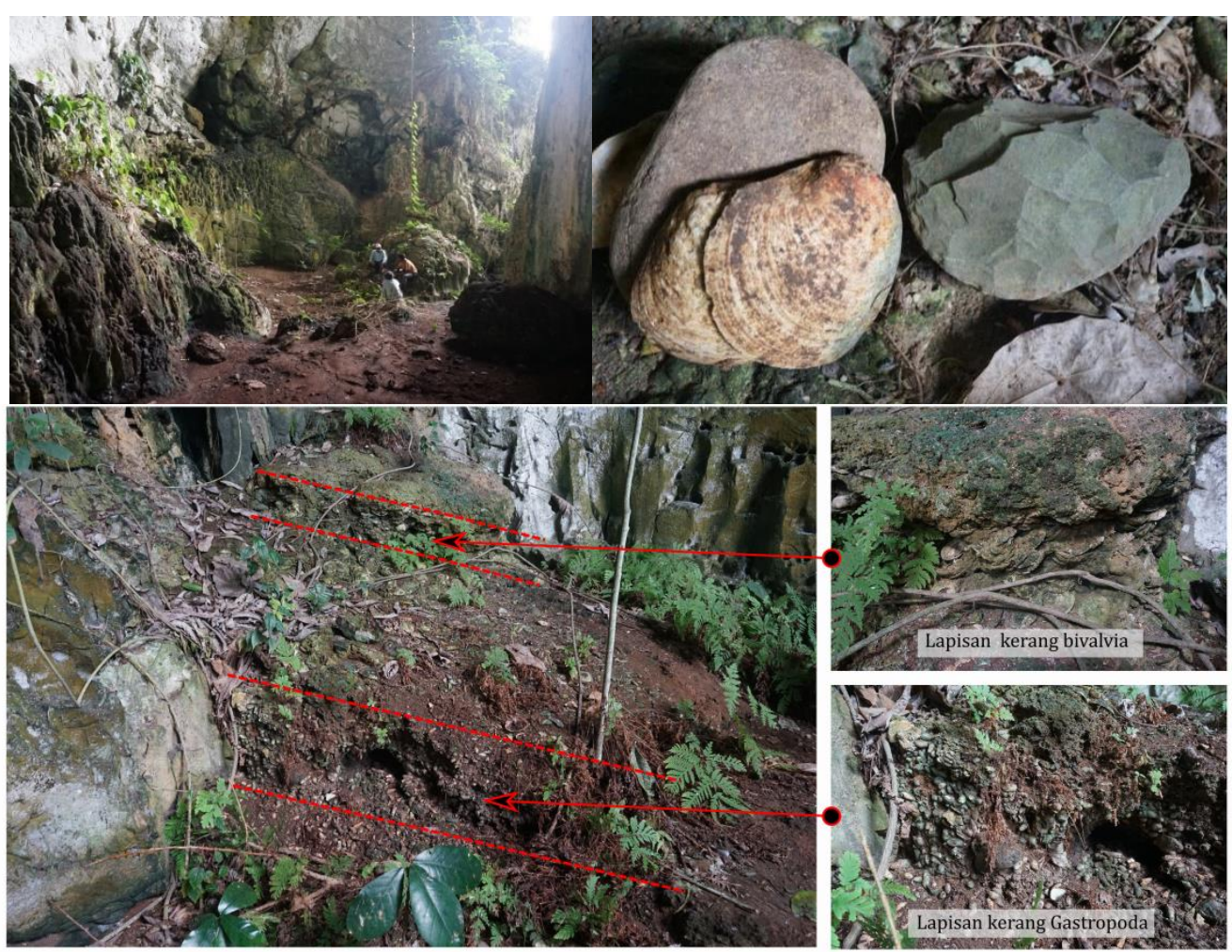

Figure 8. Spaces in Mabitce Cave, findings on the surface, and seashell layers (Source: Archaeology Research Office of North Sumatera, 2018) 


\section{Lhoong Pigip Cave}

Lhoong Pigip Cave is a cave located in Meunasah Krueng Village, Lhoong Sub-district. This cave is located at 5.283418 ${ }^{\circ}$ North Latitude and $95.246025^{\circ}$ East Longitude (UTM 46N 748934.68 Mt $584442.49 \mathrm{Mu}$ ). This cave is on the middle slope of a hill with the flat land in front of it. The cave is next to the Kreung Kala river. This cave is $500 \mathrm{~m}$ from the coastline. This cave has a floor surface sloping about 300 to the northwest with a length of $34 \mathrm{~m}$ and a depth of between 3.8-5 m. The cave faces the northeast with good lighting and air circulation. The floor of the cave is dry and has thin sediments. No artifacts are found in the cave. There are only fragments of Veneridae, Neritidae, Telescopium-Telescopium, and Placunidae shells (Figure 9).
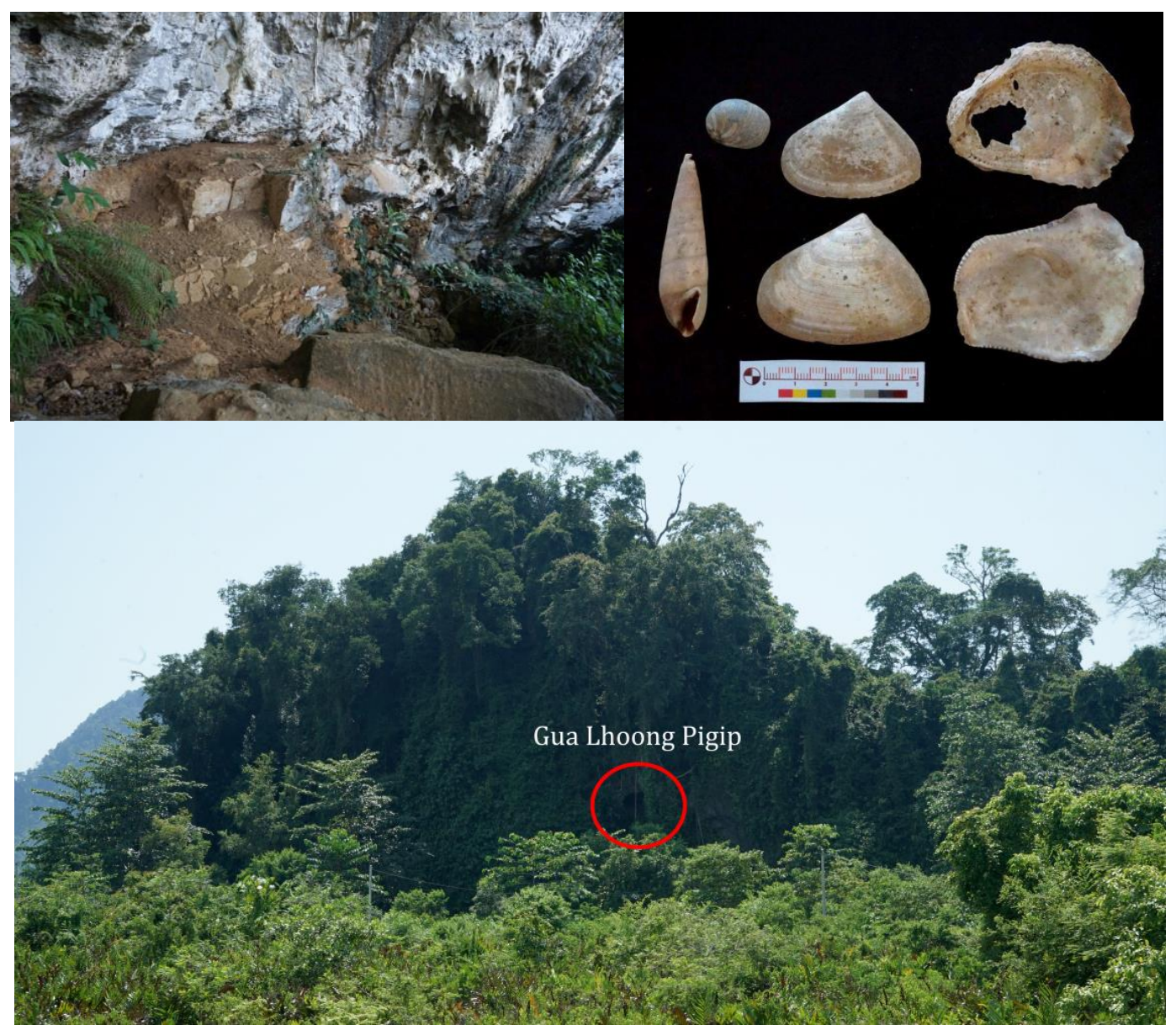

Figure 9. Cave floor, findings on the surface, and position of the Lhoong Pigip Cave (Source: Archaeology Research Office of North Suumatera, 2018)

\section{Lhoknga I Rock Shelter}

Lhoknga I Rock Shelter is a rock shelter located south of the Cement Factory of PT. Semen Andalas, precisely the east side of the Banda Aceh-Meulaboh Highway and only $100 \mathrm{~m}$ from the coast. The naming of the Lhoknga Rock Shelter was given by researchers because of no local naming. This rock shelter is on the middle slope extending from northwest to southeast. Administratively, it is 
located in Mon Ikheun Village, Lhoknga Sub-district, and is at 5.4482790 North Latitude 95.243182 ${ }^{\circ}$ East Longitude (UTM 46N 750592.15 Mt 603975.62 Mu) (Figure 10).

The environment in front of the cave is a U-shaped valley and directly borders the beach. The slope in front of the cave has a steep slope. This rock shelter has excellent lighting, air circulation, and humidity. It has thin sediments. There are no archaeological findings on the surface of the cave floor. The remnants of charcoal found in the cave walls seem to be remnants of present activities.

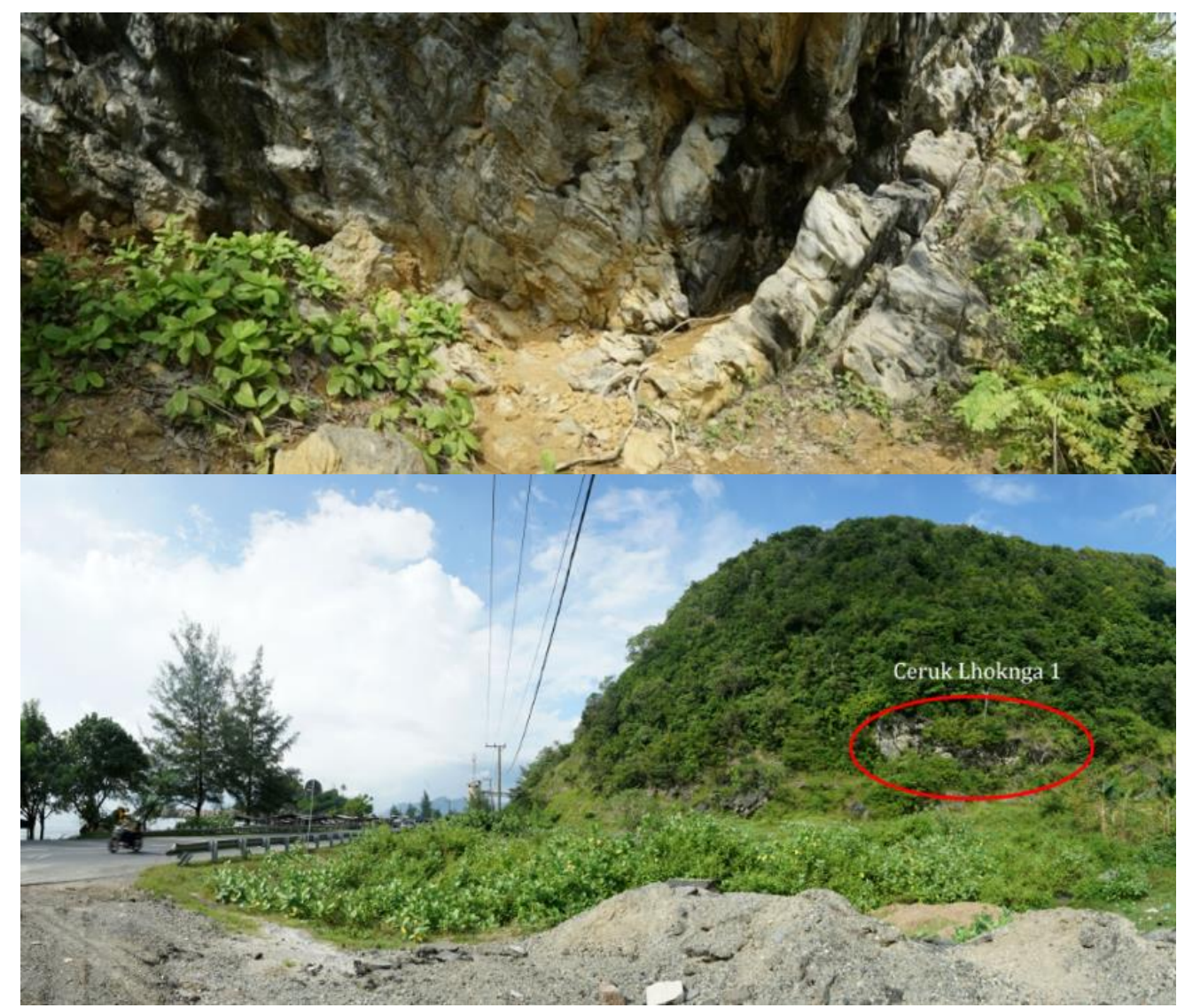

Figure 10. The floor of Lhoknga I rock shelter and the surrounding environment (Source: Archaeology Research Office of North Suumatera, 2018)

\section{Tebing Lampuuk Cave}

Tebing Lampuuk Cave is a rock shelter located in the tourist location of Lampuuk, Lhoknga Sub-district. The shelters in this location are on the lower and middle slopes of the southern Lampuuk cliffs. Some rock shelters are on the coast so that they are affected by the tide, seawater, and waves. Several rock shelters in the eastern part are found to be used as a location for lodging. This is indicated by the existence of the remaining cement and bricks. In one rock shelter that is not utilized, it appears that the sedimentary floor of the cave is very thin and only has a depth of 2-3 m. At that location, archaeological data are not found, neither artifacts, ecofacts, nor features (Figure 11). 


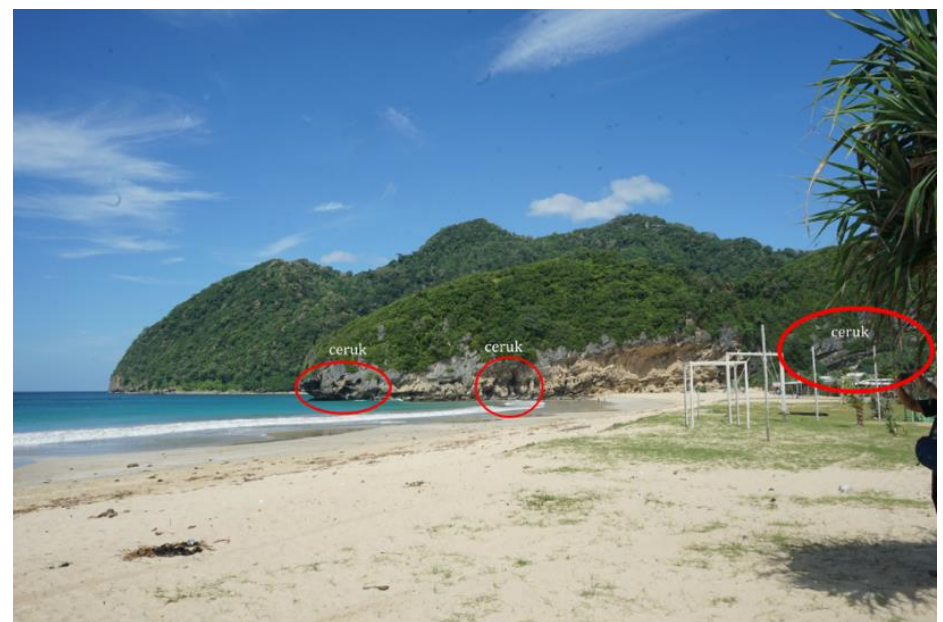

Figure 11. Tebing Lampuuk Cave and its surrounding environment (Source: Archaeology Research Office of North Suumatera, 2018)

\section{Ek Manuk Cave}

Not far from Tebing Lampuuk Cave, on the east side of Bukit Tebing Lampuuk, another group of caves, called Gua Manuk Ek, exists. In this location, two caves and several rock shelters are found on the lower and middle slopes. Manuk Ek Cave is part of an outlet for subsurface drainage streams. The position of the cave sloping $30^{\circ}$ is similar to the slope of the limestone layer on the Lampuuk cliff.

Manuk Ek Cave has a narrow entrance with poor lighting and poor air circulation. Lighting is only good in the entrance, the mouth of the cave, and the surrounding shelters. The slope in front of the cave is relatively steep and the landscape in front of it is very flat. The only archaeological finding in Manuk Ek Cave is the skull of an animal identified as Sus sp or wild boar. The skull is found on the outside of Ek Manuk cave (Figure 12).

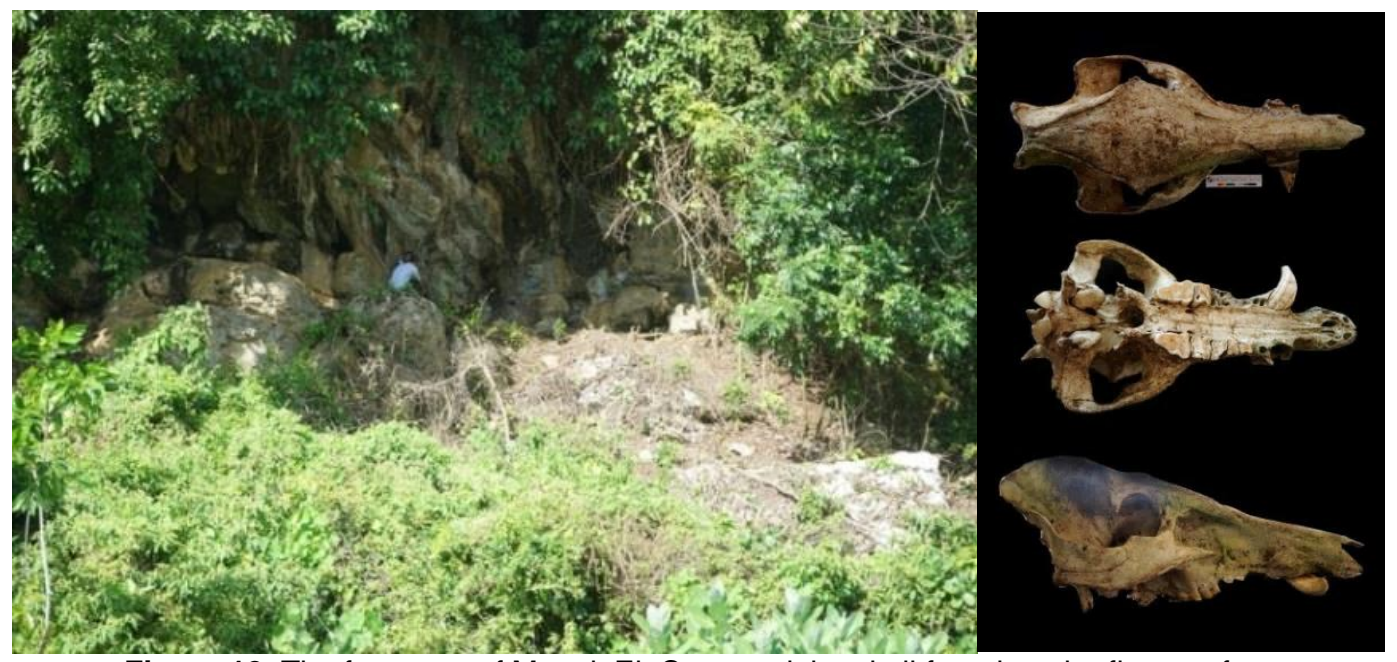

Figure 12. The front part of Manuk Ek Cave and the skull found on the floor surface (Source: Archaeology Research Office of North Suumatera, 2018) 


\section{DISCUSSIONS}

Based on the description of each surveyed cave, the identification and assessment of the cave potential according to the three parameters of inhabited caves are described in Table 3.

Table 3. The Identification of Caves and Rock Shelters in Aceh Besar Regency Based on the Parameters of Inhabited Cave

\begin{tabular}{|c|c|c|c|c|}
\hline No & Site Name & $\begin{array}{l}\text { Morphology and } \\
\text { Genesis }\end{array}$ & Environment & $\begin{array}{l}\text { Archaeological } \\
\text { Findings }\end{array}$ \\
\hline 1 & $\begin{array}{l}\text { Ek Leuntie } \\
\text { Cave }\end{array}$ & $\begin{array}{l}\text { - Spacious cave } \\
\text { - Good lighting and air } \\
\text { circulation } \\
\text { - The floor is dry and } \\
\text { relatively flat } \\
\text { - Thin sediment, } \\
\text { because of mining } \\
\text { activities }\end{array}$ & $\begin{array}{l}\text { - Subsurface river } \\
\text { outlet } \\
\text { - Located on the } \\
\text { lower slope } \\
\text { - The surrounding } \\
\text { environment is } \\
\text { relatively flat } \\
\text { - Close to a beach }\end{array}$ & $\begin{array}{l}\text { - Pottery fragments } \\
\text { - Fireplace features } \\
\text { - Lithic artifacts (?) } \\
\text { - Shell fragments }\end{array}$ \\
\hline 2 & Pari Cave & $\begin{array}{l}\text { - Spacious } \\
\text { cave } \\
\text { - Poor lighting } \\
\text { and air circulation } \\
\text { - The floor is dry and } \\
\text { relatively flat } \\
\text { - Thick sediment } \\
\text { despite } \\
\text { mining activities }\end{array}$ & $\begin{array}{l}\text { - Lower location } \\
\text { - The surrounding } \\
\text { environment is } \\
\text { relatively flat } \\
\text { - Close to a river and } \\
\text { a beach }\end{array}$ & - Islamic Tomb \\
\hline 3 & $\begin{array}{l}\text { Tuandigedong } \\
\text { Cave }\end{array}$ & $\begin{array}{l}\text { - Spacious cave } \\
\text { - Relatively good air } \\
\text { circulation } \\
\text { - Lighting only on the } \\
\text { front } \\
\text { - The floor is dry } \\
\text { and relatively flat }\end{array}$ & $\begin{array}{l}\text { - Located on the } \\
\text { lower slope } \\
\text { - The surrounding } \\
\text { environment is } \\
\text { relatively flat } \\
\text { - Close to a river and } \\
\text { a beach }\end{array}$ & $\begin{array}{l}\text { - Islamic Tomb } \\
\text { - Animal bone } \\
\text { fragments } \\
\text { - Shellfish fragments } \\
\text { - Lithic artifacts (?) } \\
\text { - Andesite stone } \\
\text { manuport }\end{array}$ \\
\hline 4 & Udang Cave & $\begin{array}{l}\text { - Narrow mouth } \\
\text { - Poor lighting and air } \\
\text { circulation }\end{array}$ & $\begin{array}{l}\text { - Located near a river } \\
\text { - Located on the } \\
\text { lower slope } \\
\text { - The surrounding } \\
\text { environment is } \\
\text { relatively flat } \\
\text { - Close to a river and } \\
\text { beach }\end{array}$ & - None \\
\hline 5 & $\begin{array}{l}\text { Pucuk Krueng } \\
\text { Cave }\end{array}$ & $\begin{array}{l}\text { - Active cave } \\
\text { - The subsurface } \\
\text { river network } \\
\text { outlet } \\
\text { - The cave is still } \\
\text { flooded }\end{array}$ & $\begin{array}{l}\text { Located on the } \\
\text { lower slope }\end{array}$ & - None \\
\hline 6 & $\begin{array}{l}\text { Menasah } \\
\text { Krueng I Cave }\end{array}$ & $\begin{array}{l}\text { - The space is } \\
\text { narrow } \\
\text { - Vertical cave } \\
\text { space } \\
\text { - Poor lighting and air } \\
\text { circulation }\end{array}$ & $\begin{array}{l}\text { - Located on the } \\
\text { lower slope } \\
\text { - The entrance } \\
\text { located on the } \\
\text { middle slope }\end{array}$ & - Ceramic Fragments \\
\hline
\end{tabular}




\begin{tabular}{|c|c|c|c|c|}
\hline No & Site Name & $\begin{array}{c}\text { Morphology and } \\
\text { Genesis }\end{array}$ & Environment & $\begin{array}{l}\text { Archaeological } \\
\text { Findings }\end{array}$ \\
\hline 7 & Mabitce Cave & $\begin{array}{l}\text { - Spacious cave } \\
\text { - Lighting and air } \\
\text { circulation are very } \\
\text { good } \\
\text { - The floor is dry and } \\
\text { relatively flat } \\
\text { - Thick sediment } \\
\text { although } \\
\text { widely mined }\end{array}$ & $\begin{array}{l}\text { - Close to a river } \\
\text { - The entrance } \\
\text { located on the } \\
\text { middle slope } \\
\text { - The front outside } \\
\text { environment is flat }\end{array}$ & $\begin{array}{l}\text { - Sumatralith } \\
\text { - Glass bottle } \\
\text { fragments } \\
\text { - Andesite stone } \\
\text { manuport } \\
\text { - Shellfish } \\
\text { fragments } \\
\text { - Features of } \\
\text { a shell layer }\end{array}$ \\
\hline 8 & $\begin{array}{l}\text { Lhoong Pigip } \\
\text { Cave }\end{array}$ & $\begin{array}{l}\text { - Spacious cave } \\
\text { - Good lighting } \\
\text { and air circulation } \\
\text { - Dry floor with a } 30^{\circ} \\
\text { slope } \\
\text { - Thin sediment }\end{array}$ & $\begin{array}{l}\text { - The river is in front } \\
\text { of the cave } \\
\text { - Very close to a } \\
\text { beach } \\
\text { - Located on the } \\
\text { middle slope }\end{array}$ & - Shellfish fragments \\
\hline 9 & $\begin{array}{l}\text { Lhoknga } 1 \\
\text { Rock Shelter }\end{array}$ & $\begin{array}{l}\text { The rock } \\
\text { shelter is } \\
\text { not too spacious } \\
\text { - Good lighting and air } \\
\text { circulation } \\
\text { - Thin sediment } \\
\text { Dry floor }\end{array}$ & $\begin{array}{l}\text { Located near a } \\
\text { beach } \\
\text { The mouth of the } \\
\text { cave located on a } \\
\text { steep slope }\end{array}$ & - None \\
\hline 10 & $\begin{array}{l}\text { Tebing } \\
\text { Lampuuk } \\
\text { Cave }\end{array}$ & $\begin{array}{l}\text { - The interior is } \\
\text { narrow but the } \\
\text { entrance } \\
\text { is wide } \\
\text { - Good lighting and air } \\
\text { circulation } \\
\text { - No sediment }\end{array}$ & $\begin{array}{l}\text { - Located by a beach } \\
\text { - Located on the } \\
\text { middle slope to the } \\
\text { bottom of the } \\
\text { Lampuuk cliff }\end{array}$ & - None \\
\hline 11 & $\begin{array}{l}\text { Ek Manuk } \\
\text { Cave }\end{array}$ & $\begin{array}{l}\text { - Relatively spacious } \\
\text { cave } \\
\text { - Narrow mouth } \\
\text { - The floor surface is } \\
\text { slanted } 30^{\circ} \\
\text { - Thin sediment }\end{array}$ & $\begin{array}{l}\text { - Located on a } \\
\text { hillside slope } \\
\text { - Close to a } \\
\text { beach } \\
\text { - The valley } \\
\text { in front of } \\
\text { the cave is } \\
\text { relatively flat }\end{array}$ & - Animal skull \\
\hline
\end{tabular}

Table 4. Potential Assessment and Cave Categories

\begin{tabular}{llcccc}
\hline No & \multicolumn{1}{c}{ Sites } & $\begin{array}{c}\text { Morphology } \\
\text { and } \\
\text { Genesis }\end{array}$ & Environment & $\begin{array}{c}\text { Parameter } \\
\text { Archaeologic } \\
\text { al Findings }\end{array}$ & Category \\
\hline 1 & Ek Leuntie Cave & $\mathrm{P}$ & $\mathrm{P}$ & $\mathrm{P}$ & Potential I \\
\hline 2 & Pari Cave & $\mathrm{P}$ & $\mathrm{P}$ & $\mathrm{NP}$ & Potential II \\
3 & Tuandigedong Cave & $\mathrm{P}$ & $\mathrm{P}$ & $\mathrm{P}$ & Potential I \\
4 & Udang Cave & $\mathrm{NP}$ & $\mathrm{P}$ & $\mathrm{NP}$ & Not Potential \\
5 & Pucuk Krueng Cave & $\mathrm{NP}$ & $\mathrm{NP}$ & $\mathrm{NP}$ & Not Potential \\
6 & $\begin{array}{l}\text { Meunasah Krueng I } \\
\text { Cave }\end{array}$ & $\mathrm{NP}$ & $\mathrm{P}$ & $\mathrm{P}$ & Not Potential \\
7 & Mabitce Cave & $\mathrm{P}$ & $\mathrm{P}$ & $\mathrm{P}$ & Potential I \\
8 & Lhoong Pigip Cave & $\mathrm{P}$ & $\mathrm{P}$ & $\mathrm{NP}$ & Potential II \\
9 & $\begin{array}{l}\text { Lhoknga 1 Rock } \\
\text { Shelter }\end{array}$ & $\mathrm{P}$ & $\mathrm{P}$ & $\mathrm{NP}$ & Potential II
\end{tabular}




\begin{tabular}{llcccc}
10 & $\begin{array}{l}\text { Tebing Lampuuk } \\
\text { Cave }\end{array}$ & NP & NP & NP & Not Potential \\
11 & Ek Manuk Cave & P & P & NP & Potential II \\
\hline & Note: $(P)=$ Potential; $(T P)=$ Not Potential & &
\end{tabular}

Three caves are categorized as Potential I, i.e. Ek Leuntie Cave, Tuandigedong Cave, and Mabitce Cave where all three parameters have potential values. These caves have a morphology that qualifies as an inhabited cave. The environmental resources that support the settlement in the cave are also very easy to obtain. Surface findings as an early indication of the use of this cave are also found in all three locations. The caves that have the potential to be further investigated include Mabitce Cave and Tuandigedong Cave. In both caves, several surface evidences are found in the form of a sumatralith stone tools, andesite stone manuport, shells, fauna remnants, and also bottle fragments. One other cave can also be studied, i.e. Leuntie Ek Cave, but it has less sedimentary floor especially that near the mouth of the cave. On the remaining sediment, residual combustion features, potsherds, andesite stone manuport, and shells are found.

The sumatralith stone tools found in Mabitce Cave illustrates the influence of Hoabinh culture. The Sumatralith stone tools have similar cultural characteristics found at the Bukit Kerang site in Aceh's Eastern Coast and also in the interior of Aceh (Wiradnyana, 2011; Figure 13). Northern Sumatra in prehistoric times had one distinctive culture that has similarities with Mainland of Southeast Asia, namely Hoabinh. The term Hoabinh has been used since the 1920s to refer to a stone tool industry that is characterized by splintering one or two sides of its surface so that all edges can be sharp. The splintering shows a variety of shapes from rectangle to the triangle and some of them have waisted shapes. Such stone tools are found at Hoabinh sites together with shales, annealing stones and ground stones of various sizes, spatula, and taper of bones and remains of a flexed burial sprinkled with red rocks (hematite). The Hoabinh spread throughout mainland Southeast Asia, in South China and Taiwan. The dating done at several Hoabinh sites show that this culture existed in 18,000-3,000 years ago (Bellwood, 2007, pp. 238-241). The bearers of this culture tend to have an economy that emphasizes hunting and food collection on the coast and inland. Hoabinhian tends to be found in the pre-pottery period. In general, this cultural distribution occurred in mainland Southeast Asia to the eastern coast of Sumatra. Hoabinh is seen as techno-complex from the Upper Pleistocene to the beginning of the Holocene. This view is reinforced by long periods, homogeneity, and certain unity in time and geographical space (Forestier, 2007, p. 47). 


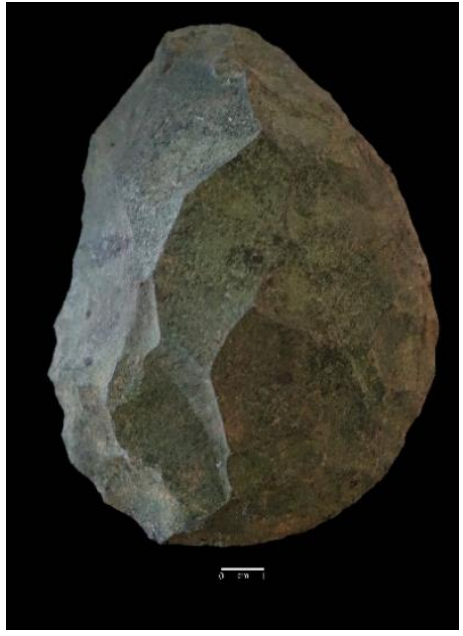

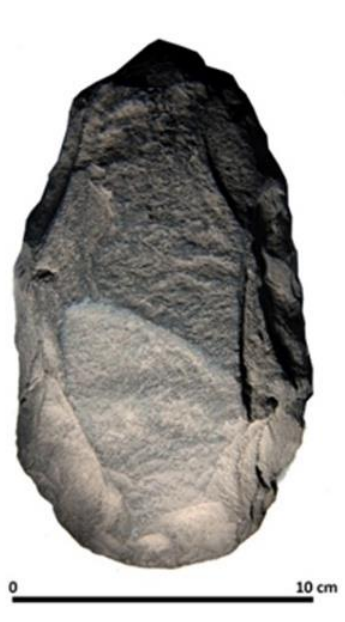

b

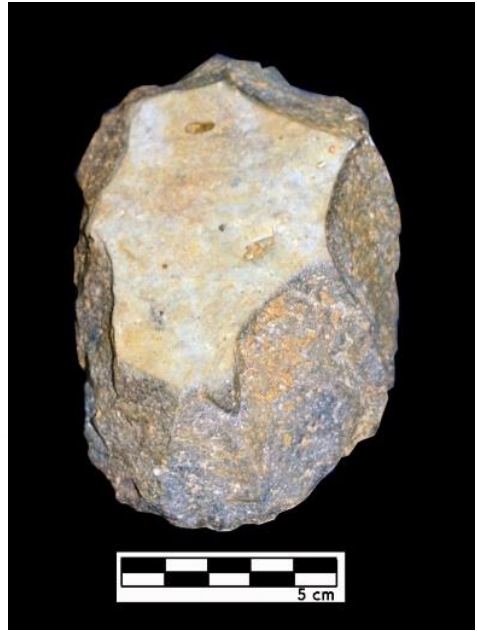

Figure 13. Sumatralith stone tools from Mabitce Cave (a), Bukit Kerang Sukajadi Hill (b), and Bukit Kerang Pangkalan (c)

(Source: Archaeology Research Office of North Suumatera, 2018 (a); North Sumatera State Museum, 2011 (b); Archaeology Research Office of North Suumatera, 2009 (c)

The four caves that are categorized as Potential II include Pari Cave, Lhoong Pigip Cave, Lhoknga I Rock Shelter, and Ek Manuk Cave. In general, the four caves have a morphology that qualifies as an inhabited cave. The surrounding environment also supports the existence of the settlement. The location of the cave which is mostly on the middle slope of a hill and the lower slope provides easy access to reach. The slope degree is also very supportive of settlement in caves and rock shelters. The physical aspects supporting a settlement such as rivers, beaches, and food sources are also available in the location.

Four potential caves include Meunasah Krueng I Cave, Pucuk Krueng Cave, Tebuk Lampuuk Cave, and Udang Cave. Pucuk Kreung Cave is an outlet for underground streams and is still functioning until today. At the top, there are several rock shelters but cannot be surveyed because they require special equipment. Meunasah Krueng I Cave is the outer part of the vertical ponor/cave which is now covered by soil. Meunasah Krueng I Cave has no potential for settlement because of the narrow cave space and vertical shaft.

\section{CONCLUSIONS}

The results of the cave and rock shelter survey in Aceh Besar Regency found eleven caves and rock shelters. Of the eleven caves, only seven caves are categorized as inhabited caves. Three caves (Mabitce Cave, Tuandigedong Cave, and Ek Leuntie Cave) are categorized as 'Potential I', i.e. qualified as a settlement and potential to be archaeologically studied. The other four caves are categorized as 'Potential II', meaning qualified as a settlement but not potential for further investigation. The other four caves are 'potential' caves for both settlements and research locations. These results are preliminary information related to the settlement potential of caves and rock shelters in Aceh Besar Regency which can be used as preliminary data to find out past life on the western coast of Aceh. The existence of three caves that are very potential to be used as a settlement and 
archeological research site provides opportunities for further data collection through excavation to provide a complete insight into the past life in Aceh in particular and northern Sumatra in general.

\section{ACKNOWLEDGEMENTS}

I would like to express my sincere gratitude to Nasfi, a staff in Aceh Besar Regency's Education and Culture Office, who was very helpful in the process of finding data and a good translator in the process of communication with residents around the research locations. My gratitude also goes to Andi Irfan Syam, S.S., M.Si. and Lucky Armanda, S.S., M.Si. for helping me demonstrate other potentials of caves and rock shelters in Aceh Besar Regency. 


\section{DAFTAR PUSTAKA}

Bellwood, P. (2007). Prehistory of the Indo-Malaysian Archipelago (Revised Ed). Canberra: ANU E-Press.

Butzer, K. W. (2006). Archaeology as Human ecology: Methods and theory for contextual approach (Re-Isuuedi). Retrieved from https://books.google.co.id/ books?hl=en\&lr=\&id=EDdC2BJJ7lcC\&oi=fnd\&pg=PR11\&dq=settlement + ar chaeology+butzer\&ots $=$ ATqbBVZZ27\&sig $=\mathrm{u} 8 \mathrm{~W} 7 \mathrm{CWvRwMTm2Ori4qON1J}$ $\mathrm{YEaFs \& redir \_ esc}=\mathrm{y} \# \mathrm{v}=$ onepage\& $\mathrm{q}=$ settlement archaeology butzer\&f=false

Indonesia, Masyarakat Speleologi. (2013). Basis Data Gua dan Mata Air. Retrieved 20 September 2017, from http:/ / peta.caves.or.id/reports

Drawhorn, G. M. (2000). Indonesian-International Sumatran Cave Research and Exploration Expedition. Retrieved from www.csus.edu/indiv/d/drawhorng/

Forestier, H. (2007). Ribuan Gunung, Ribuan Alat Batu, Prasejarah Song Keplek, Gunung Sewu, Jawa Timur. Jakarta: Kepustakaan Populer Gramedia dengan Effeo, IRD, Puslitbang Arkenas dan Forum Jakarta- Paris.

Legge, A. J. (1972). Cave Climates. In E. S. Higgs (Ed.), Paper in Economic Prehistory (h. 97-103). Cambridge: Cambridge University Press.

Rubin, C. M., Horton, B. P., Sieh, K., Pilarczyk, J. E., Daly, P., Ismail, N., \& Parnell, A. C. (2012). Highly variable recurrence of tsunami in the 7.400 years before the 2004 Indian Ocean tsunami. Nature Comunication.

Setiawan, T. (2012). Permukiman Gua Di Kabupaten Bener Meriah (Sebuah Analis Pendahuluan). Sangkhakala, 16(1).

Setiawan, T. (2018). Survei Gua dan Ceruk Arkeologis di Pesisir Barat Aceh. Medan.

Subroto, P. (1995). Pola-Pola Zonal Situs-Situs Arkeologi. Berkala Arkeologi, XV (Edisi(Manusia dalam Ruang Studi Kawasan dalam Arkeologi).

UKM PA Leuser. (2004). Term of Reference (TOR)/KerangkaSeminar Nasional Kawasan Karst 2004. $\quad$ Retrieved from http://groups.yahoo.com/group/subterra-id/message/337

Wiradnyana, K. (2011). Prasejarah Sumatera Bagian Utara: Kontribusi pada Kebudayaan Kini. Jakarta: Yayasan Obor Indonesia.

Wiradnyana, K., \& Setiawan, T. (2011). Gayo Merangkai Identitas. Jakarta: Yayasan Obor Indonesia.

Yuwono, J. S. E. (2005). Mozaik Purba Gunung Sewu: Hipotesis Hasil Eksplorasi Gua-gua Arkeologis Di Kecamatan Tanjungsari-Gunungkidul. Gunung Sewu Indonesian Cave and Karst Journal., 1 (1 April), 40-51. 


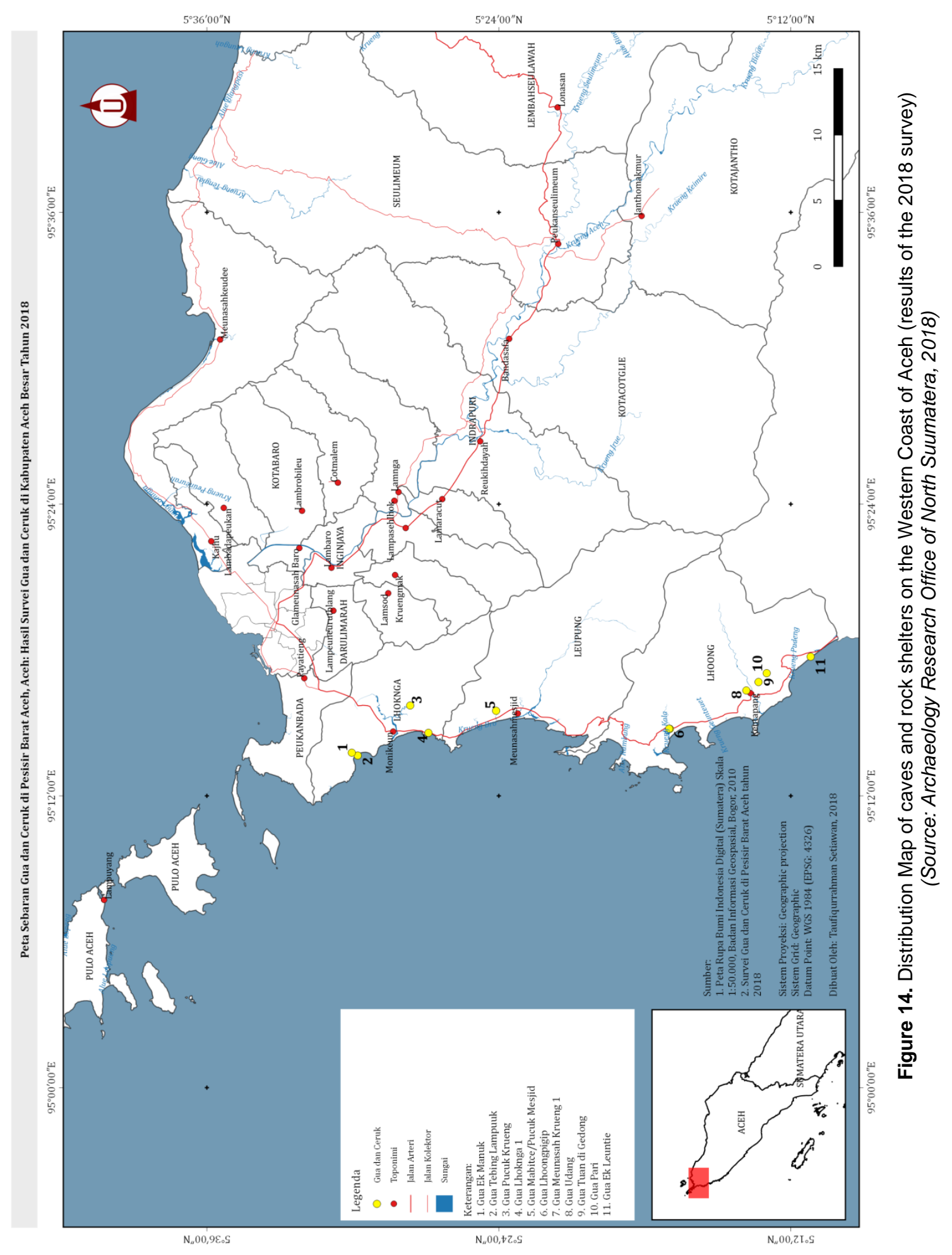

